\title{
Contents
}

Editorial

Climate change: time to redefine our profession

A Yngve, B Margetts, M Tseng, R Hughes and G Cannon

Climate change and the public health nutrition agenda

$R$ Hughes

An investigation of the ways in which public health nutrition policy and practices can address climate change

$H$ Sulda, J Coveney and M Bentley

\section{Monitoring and surveillance}

Obesity and cardiometabolic risk factors in a representative population of Iranian adolescents and adults in comparison to a Western population: the Isfahan Healthy Heart Programme

$N$ Sarrafzadegan, R Kelishadi, ZD Siadat, A Esmaillzadeh, A Solhpour, S Shirani, $G$ Naderi, S Asgary, G Sadri, A Khosravi and A Bahonar

Food intake of young people with a migration background living in Germany

$C$ Kleiser, GBM Mensink, H Neuhauser, L Schenk and B-M Kurth

Iron status in pregnant women in the Republic of Seychelles

EM Duffy, MP Bonham, JMW Wallace, C-K Chang, PJ Robson, GJ Myers,

PW Davidson, TW Clarkson, CF Shamlaye and JJ Strain

Hypothesis-oriented food patterns and incidence of hypertension: 6-year follow-up of the SUN (Seguimiento Universidad de Navarra) prospective cohort

E Toledo, F de A Carmona-Torre, A Alonso, B Puchau, MA Zulet, JA Martinez and MA Martinez-Gonzalez

\section{Assessment and methodology}

Dietary intake and development of a quantitative FFQ for a nutritional intervention to reduce the risk of chronic disease in the Navajo Nation

S Sharma, M Yacavone, X Cao, M Pardilla, M Qi and J Gittelsohn

Validation of the Household Food Insecurity Access Scale in rural Tanzania

D Knueppel, M Demment and L Kaiser

Validity and reliability of an FFQ for use with adolescents in Ho Chi Minh City,

Vietnam

TK Hong, MJ Dibley and D Sibbritt

\section{Biological and behavioural determinants}

Effects of peer influence on dietary intake and physical activity in schoolchildren

$T$ Finnerty, S Reeves, J Dabinett, YM Jeanes and C Vögele

Effect of parental overweight and serum leptin levels on the manifestation of overweight in 7-year-old Korean children

IK Kim, H-J Lee, JH Kang and J Song

\section{Social, economic, political and environmental determinants}

Children's magazines: reading resources or food marketing tools?

$S C$ Jones and A Reid

Modern organic and broiler chickens sold for human consumption provide more energy from fat than protein

$Y$ Wang, C Lehane, K Ghebremeskel and MA Crawford

Marketing foods to children and adolescents: licensed characters and other promotions on packaged foods in the supermarket

IL Harris, MB Schwartz and KD Brownell

Cambridge Journals Online For further information about this journal please go to the journal website at: journals.cambridge.org/phn
$\widehat{\Upsilon}^{\circ}$ Www.fsc.org Cert no. T-Coc-002769
Q 1996 Forest Stewardship Council
CAMBRIDGE UNIVERSITY PRESS 
Public Health Nutrition (PHN) provides a forum for the presentation of original research findings and high quality reviews of key topics, and for discussion of and debate on of current issues and controversies. It also publishes special issues on major topics of interest. Our field includes research, scholarship, and discussions on public health nutrition, that take a population, health promoting and preventive approach. Papers that do not have this emphasis may be directed to more appropriate journals. Potential contributors are encouraged to read the aims and scope of the journal, and to note and follow the guidelines set out below.

\section{Content:}

- Original research findings and scientific reviews are published as full papers usually less than 5000 words, including references.

- Editorials express the opinion of the journal, as represented by its central editorial team, on topics judged by them to be important. Editorials, including guest editorials, are usually co-ordinated and developed by the editorial team.

- Position papers, including declarations and other statements of policy, may be invited or unsolicited.

- Invited commentaries and book reviews are expressions of opinion on a topical subject. These are commissioned by the members of the editorial team.

- Letters to the Editors are usually in response to material published in PHN. Submissions are sent to the author for comment and, when possible, published together with the author's reply.

Submission: PHN operates an online submission and reviewing system (eJournalPress). All manuscripts must be submitted online at http://phn.msubmit.net/. If any difficulties are encountered, please contact the Publications Office at phn@nutsoc.org.uk

Refereeing: Review articles and articles reporting original research are subject to external review by two or more referees who evaluate manuscripts based on their importance, relevance, and originality. Authors are asked to submit names and contact details (including email address) of up to four potential referees. All other contributions (editorials, position papers, invited commentaries, book reviews, and letters to the Editors) undergo an internal review process by at least two members of the editorial team. Invited commentaries and book reviews may also be checked externally as necessary to avoid technical errors and to improve salience.

Copyright: At the time of acceptance, authors will be asked to provide a completed copy of the 'Licence to Publish' (in lieu of copyright transfer), available at https://www.nutritionsociety. $\mathrm{org} /$. It is the author's responsibility to obtain written permission to reproduce any material (including text and figures) that has appeared in another publication.

Preparation of manuscripts: Please refer to the full Directions to Contributors on our website (http://www.nutritionsociety. org). Manuscripts should be in clear and concise English, and spelling should follow the Oxford English Dictionary. For authors whose native tongue is not English, in-house editorial attention to their contributions will improve clarity. On acceptance, all contributions are subject to editorial amendment to conform to house style. Manuscripts should be prepared in a common word processing package (Word for Windows is preferred) in Times New Roman or other common typeface, prepared with doublespaced text, at least $2 \mathrm{~cm}$ margins, and page and line numbers. Standard abbreviations and SI units must be used.

\section{Disclosure of financial support and any competing}

interests. The submission must include a statement within an Acknowledgements section reporting any competing interests, all sources of funding, and the nature of the contribution of each author to the manuscript. If there are no competing interests, this must be stated. Authors are asked to provide this information during the submission process and should not include it as part of the manuscript to allow for double-blind reviewing.

\section{Arrangement of papers:}

1. Title page should include the article title, author(s), affiliation(s), up to eight keywords, one author identified for correspondence (with full postal address, telephone and fax numbers, and email address), and a running title of up to 45 characters. The title page should be submitted online as a separate cover letter, not as part of the manuscript, to enable double-blind reviewing.

2. Abstract should be structured, usually using the following internal headings: Objective, Design, Setting, Subjects, Results, Conclusions. Abstracts should be intelligible without reference to text or figures and should not exceed 250 words.

3. Text should be divided under headings (typically to include Introduction, Methods, Results, Discussion and Conclusions), and sub-headings as appropriate. Conclusions should include recommendations that derive from the research and that are concrete, feasible, and potentially effective. Emphasising that more research is needed is usually not necessary unless there is specific reason to say so.

4. Acknowledgements (sources of funding, competing interests declaration, authorship responsibilities, acknowledgements) should be provided during the submission process, not as part of the manuscript.

5. References should be in Vancouver style. Please refer to the full Directions to Contributors.

6. Tables should be reduced to the simplest form and should not be used where text or figures give the same information. Each table must be accompanied by a clear and concise caption that is comprehensible without reference to the text. Longer tables may be published online only.

7. Figures should be numbered, and legends should be provided. Each figure, with its legend, should be comprehensible without reference to the text and include definitions of abbreviations.

Proofs: Correspondence and proofs for correction will be emailed to the first named author unless otherwise indicated. The author will receive a PDF proof for checking. It is important that proofs be returned promptly. Authors may be charged for any alterations in excess of $10 \%$ of original setting.

Offprints: The corresponding author will receive a copy of the issue and a PDF of the published paper free of charge. Offprints are available to purchase and can be ordered before publication. 


\title{
Public Health Nutrition
}

\author{
Volume 13, 2010 ISSN: 1368-9800 \\ journals.cambridge.org/PHN
}

\section{Publishing, Production, Marketing, and Subscription Sales Office:}

Cambridge University Press

The Edinburgh Building

Shaftesbury Road

Cambridge CB2 8RU

UK

\section{For Customers in North America:}

Cambridge University Press

Journals Fulfillment Dept

100 Brook Hill Drive

West Nyack

New York 10994-2133

USA

\section{Publisher: Katy Christomanou}

\section{Special sales and supplements}

This journal accepts advertising and inserts. We also provide bulk reprints of suitable papers to meet teaching or promotional requirements. The journal also publishes supplementary material including conference proceedings on behalf of academic and corporate sponsors. Please contact Katy Christomanou at Cambridge University Press for further details

(email: kchristomanou@cambridge.org).

\section{Subscription information}

Public Health Nutrition is an international journal published 12 times per year by Cambridge University Press on behalf of the Nutrition Society. The online edition is available at

journals.cambridge.org/PHN, with free table of contents alert (upon registration).

\section{Annual subscription rates \\ Volume 13, 2010 (12 issues): Internet/print package: $£ 697 / \$ 1337$ Americas only/€1117 EU only Internet only: $£ 589 / \$ 1116$ Americas only/€936 EU only}

Any supplements to this journal published in the course of the annual volume are normally supplied to subscribers at no extra charge.

Claims for non-receipt of journal issues will be considered on their merit and only if the claim is received within six months of publication. Replacement copies supplied after this date will be chargeable.

Advertising: The Nutrition Society is willing to include
advertisements in its journals. However, it will retain the right
to make decisions on which advertisements are acceptable and which are not, and will not be obliged to give reasons to prospective advertisers for its decisions. The appearance of an advertisement in the Society's journals does not imply endorsement by the Society. For further details, please contact Cambridge University Press.

Back volumes will be available in due course. Please contact Cambridge University Press for further information.

US POSTMASTERS: Please send address corrections to

Public Health Nutrition

Cambridge University Press

100 Brook Hill Drive

West Nyack

New York 10994-2133

USA

Notes for Authors are available from the publisher at the given address and can be found inside the back cover.

Offprints: The author (or main author) of an accepted paper will receive a free PDF of their paper and a copy of the issue in which their paper has been published. Additional offprints are available for a fee and must be ordered at proof stage. No page charges are levied by this journal.

Copyright: As of 1 January 2001 the copyright of all articles submitted to Public Health Nutrition are retained by the authors or their institutions. For articles prior to this date permission for reproduction of any part of the journal (text, figures, tables or other matter) in any form (on paper, microfiche or electronically) should be sought directly from the Society, at: The Editorial Office, The Nutrition Society, 10 Cambridge Court, 210 Shepherds Bush Road, Hammersmith, London, W6 7NJ, UK.

Disclaimer: The information contained herein, including any expression of opinion and any projection or forecast, has been obtained from or is based upon sources believed by us to be reliable, but is not guaranteed as to accuracy or completeness. The information is supplied without obligation and on the understanding that any person who acts upon it or otherwise changes his/her position in reliance thereon does so entirely at his/her own risk. Neither the Society, nor Cambridge University Press accepts responsibility for any trade advertisement included in this publication.

This journal issue has been printed on FSC-certified paper and cover board. FSC is an independent, non-governmental, not-for-profit organization established to promote the responsible management of the world's forests. Please see www.fsc.org for information.

Typeset by Macmillan India Limited, Bangalore, India and Printed in Europe by Bell and Bain, Glasgow.

Public Health Nutrition is covered in Science Citation Index Expanded (Web of Science), Current Contents, Agriculture, Biology \& Environmental Sciences, Current Contents, Clinical Medicine, CAB ABSTRACTS ${ }^{\mathbb{R}}$, Global Health, Index Medicus ${ }^{\circledR}\left(\right.$ MEDLINE $\left.^{\circledR}\right)$, EMBASE, Excerpta Medica, BIOSIS ${ }^{\circledR}$ Database and CINAHL ${ }^{\circledR}$ Database Public Health Nutrition participates in the following initiatives: HINARI by WHO and AGORA by FAO. 


\section{Interventions}

Leaf concentrate as an alternative to iron and folic acid supplements for anaemic adolescent girls: a randomised controlled trial in India

$S$ Vyas, SM Collin, E Bertin, GJ Davys and B Mathur

Persistence of severe iodine-deficiency disorders despite universal salt iodization in an iodine-deficient area in northern India

$S$ Yadav, SK Gupta, MM Godbole, M Jain, U Singh, PV Pavithran, R Boddula, A Mishra, A Shrivastava, A Tandon, M Ora, A Chowhan, M Shukla, $N$ Yadav, $S$ Babu, M Dubey and PK Awasthi

Information design to promote better nutrition among pantry clients: four methods of formative evaluation

SH Evans, P Clarke and C Koprowski

Effectiveness of prevention programmes for obesity and chronic diseases among immigrants to developed countries - a systematic review AMN Renzaho, D Mellor, K Boulton and B Swinburn 